\title{
Perbandingan Tulang dan Lokomosi \\ pada Quadrupedal dan Bipedal
}

\author{
Arif Wicaksono $^{1}$, Sasanthy Kusumaningtyas ${ }^{2}$ \\ ${ }^{1}$ Departemen Anatomi Medik, Program Studi Pendidikan Dokter, FK UNTAN \\ ${ }^{2}$ Departemen Anatomi, Fakultas Kedokteran Universitas Indonesia
}

\begin{abstract}
Abstrak
Latar belakang. Antropologi masih memperlihatkan ketertarikan dalam membandingkan struktur skeletal dan lokomosi antara manusia dan primata. Manusia dikatakan berkembang menjadi bipedal karena proses evolusi ribuan tahun dari primata. Metode. Penelitian ini membahas perubahan anatomi yang terjadi pada quadrupedal dan bipedal secara umum kemudian mengkhususkan pada anatomi skeleton apendiculare, komparasinya dan hubungannya dengan lokomosi. Hasil. Terdapat perbedaan pada beberapa detil tulang antara bipedal dan quadrupedal. Kesimpulan. Bentuk tulang pada manusia bipedal dan primata quadrupedal mirip tetapi terdapat perbedaan pada ukuran dan bentuk dari skeleton appendicularnya yang menyebabkan perbedaan pembagian/penerusan beban, berbedaan lokomosi dan perbedaan energi yang diperlukan untuk melakukan lokomosi.
\end{abstract}

Kata Kunci : Lokomosi, quadrupedal, bipedal

Background. There was still an interest in comparing skeletal structure and locomotion of human and primate. Method. This research aimed to determine anatomical changes happened to quadrupedal and bipedal, especially on appendiculare skeletons, the comparison and the relation to locomotion. Result. There was a difference on some details of skeletons in quadrupedal and bipedal. Conclusion. The skeletons in quadrupedal and bipedal are similar but different in the size and shape of its appendiculare skeletons, causing the difference in weight bearing and locomotion.

Key words : Locomotion, quadrupedal, bipedal 
PENDAHULUAN

Pertanyaan yang paling lama ditanyakan pada kita dan disiplin ilmu anatomi bahkan pada masyarakat adalah bagaimana dan kenapa manusia berjalan dengan dua kaki (bipedal).

Para paleoanthropologis setuju bahwa bipedal merupakan adaptasi dari hominin tetapi belum ada persetujuan awal transisi menjadi bipedal. Banyak hipotesis yang telah diajukan untuk asal mula bipedal seperti kebiasaan dan bentuk penyusun lokomosi. Penelitian kemudian dilakukan untuk melihat perubahan dari leluhur sebelumnya dan bipedal awal, taksonomi, fosil dan teori-teori yang sudah ada ${ }^{1}$.

Antropologi masih memperlihatkan ketertarikan dalam membandingkan struktur skeletal dan lokomosi antara manusia dan primata. Manusia dikatakan berkembang menjadi bipedal karena proses evolusi ribuan tahun dari primata. Banyak penelitian dilakukan untuk melihat dua tipe lokomosi yaitu bipedal pada manusia dan quadrupedal pada primata untuk melihat tupe tulang dan tipe lokomosi yang dilakukan. Penelitian menunjukkan bahwa struktur tulang mempengaruhi efisiensi tenaga dan jenis lokomosi. Struktur tulang pada manusia dan primata memang mirip tetapi ada beberapa perbedaan pada bentuk dan ukuran tulang yang mempengaruhi lokomosi ${ }^{2}$.

\section{METODE}

Penelitian ini akan membahas perubahan anatomi yang terjadi pada quadrupedal dan bipedal secara umum kemudian mengkhususkan pada anatomi skeleton apendiculare, 
komparasinya dan hubungannya dengan lokomosi.

\section{HASIL}

\section{Skeleton Appendiculare}

Skeleton appendiculare terdiri dari sepasang tungkai dan korset. Pada quadrupedal disebut tungkai depan dan tungkai belakang sedangkan pada bipedal disebut dengan tungkai atas dan bawah.

Korset pada tungkai depan disebut korset bahu atau korset dada sedangkan korset pada tungkai depan disebut dengan korset pinngul atau korset pelvis.

Vertebrata memiliki karakteristik ini dan dikatakan bahwa sirip pada ikan akan menjadi tungkai pada mamalia ${ }^{3}$.

\section{Evolusi bipedal}

Evolusi yang terjadi mencakup tiga hal yaitu perubahan volume otak, perubahan lokomosi dan perubahan budaya. Pada quadrupedal volume otak relatif kecil sedangkan pada bipedal volume otak membesar. Quadrupedal ada yang hidup di pepohonan dan sesekali turun ke darat sedangkan bipedal hidup di darat ${ }^{4}$.

\section{Adaptasi Bipedal}

Perubahan dari quadrupedal menjadi bipedal tampak dari segi anatomis tulang-tulang penyusun lokomosi. Perubahan yang terjadi adalah :

1. Perubahan posisi foramen magnum. Quadrupedal memiliki foramen magnum di belakang cranium yang menyebabkan kepala lebih tidak stabil sehingga 
membutuhkan otot-otot leher

yang besar. Bipedal memiliki

foramen magnum di dasar

cranium sehingga lebih stabil.

2. Perubahan curva spinalis.

Quadrupedal menumpu berat

badan sepanjang garis paralel

terhadap tanah dan beban

akan diteruskan ke dua

tungkai. Bipedal memiliki

lengkung spinalis sehingga

berat tubuh akan lebih

terkonsentrasi di daerah

lumbal kemudian diteruskan

ke tungkai bawah saja.

3. Perubahan tungkai. Tungkai

bawah pada quadrupedal

tidak sampai $20 \%$ dari

panjang tubuh sedangkan

tungkai bawah pada bipedal

mencapai lebih dari $30 \%$

panjang tubuh.
4. Perubahan pelvis. Pelvis pada quadrupedal panjang dan pipih sehingga kurang stabil sedangkan pada bipeal elvis pendek dan luas sehingga stabil dan dapat memudahkan transmisi berat/beban.

5. Perubahan posisi femur. Femur pada bipedal lebih mengarah ke medial, membentuk sudut yang lebih besar dibandingkan dengan quadrupedal sehingga memperluas gerakan yang diperlukan.

6. Perubahan pada kaki. Pada quadrupedal jarak ibu jari kaki dan jari lainnya jauh seperti pada tangan dan tidak memiliki lengkung kaki. Bipedal memiliki ibu jari kaki yang tersusun paralel dengan 
jari lainnya dan memiliki lengkung $\mathrm{kaki}^{4}$.

Lokomosi

quadrupedal

dan

bipedal

Dua perbedaan secara khusus pada bidang lokomosi adalah kebiasaan sehari-hari spesies tersebut dan struktur tulang yang menyusun yang memungkinkan jenis lokomosi. Manusia merupakan mamalia dengan kebiasaan bipedal yang mengunakan tungkai bawah secara dominan untuk bergerak terhadap lingkungannya. Kebanyakan primata merupakan mamalia quadrupedal yang menggunakan semua tungkainya untuk bergerak terhadap lingkungannya ${ }^{2}$.

Lokomosi bipedal memiliki dua jenis lokomosi utama yaitu berjalan dan berlari. Berjalan membutuhkan setidaknya satu kaki harus kontak secara terus menerus dengan tanah sedangkan untuk berlari kedua kaki bisa tidak mengalami kontak dengan tanah dalam waktu singkat secara simultan. Bipedal mengalami beberapa adaptasi seperti spesifikasi postcranial terutama pada tungkai bawah yang membentuk lokomosi unik. Perbedaan antara quadrupedal dan bipedal banyak ditemukan di daerah kaki tetapi beberapa perbedaan bisa juga ditemukan di daerah pelvis dan femur ${ }^{2}$.

Lokomosi quadrupedal banyak ditemukan pada beberapa mamalia termasuk primata. Tipe lokomosinya merupakan berjalan dengan sekuens lateral tidak seperti berjalan dengan sekuens diagonal seperti pada bipedal. Berjalan pada primata 
sedikit berbeda dengan berjalan/bergeraknya mamalia lain. Primata quadrupedal mengekstensikan tungkainya jauh ke arah depan, mengarahkan tungkai depan lebih ke arah kepala tergantung pada kebiasaan mereka saat itu, apakah berada di pohon atau berada di darat ${ }^{2}$.

Penelitian Richmond dkk mengkaji kemungkinan bipedal dari beberapa pendahulu/leluhur yaitu :

1. Leluhur arboreal.

Quadrupedal, membawa berat tubuh mendekati penyangga, dapat melakukan gerakan bebas pada sendi siku dan lutut, gerakan terbatas pada sendi bahu dan pelvis, berukuran tubuh relatif kecil dan tungkai depan dikatakan merupakan calon bipedal.
2. Leluhur hylobatian.

Quadrupedal dengan tipe brachiasi, memiliki tungkai belakang realtif panjang dan tungkai depan yang panjang. Gerakan sedang pada sendi lutut dan pelvis. Badan kecil dengn jari-jari yang panjang dan berkurva.

3. Leluhur quadrupedal darat. Quadrupedal dengan tipe digitigrady(penyokong jari) atau palmigrady(penyokong tangan/palmar). Sendi tangan, siku dan kaki stabil dengan jari kokoh, pendek dan lurus. Berbadan sedang

4. Leluhur knuckle-walking. Quadrupedal dengan penyokong phalanges media, sendi tangan dan siku stabil dengan thorax yang lebar ${ }^{1}$. 
PEMBAHASAN

\section{Anatomi komparatif}

Anatomi yang akan dikomparasikan antara lain:

1. Radius

2. Spatium carpometacarpalia

3. Femur

4. Humerus hylobates, pongo, gorilla, pan, homo, P.heseloni, A. anamensis, A. afarensis, A. africanus dan P. robustsus diteliti sehingga didapatkan perbedaan pada os radius dan spatium carpometacarpalia ${ }^{1}$.

Pada radius terdapat proyeksi distal. Proyeksi distal ini akan

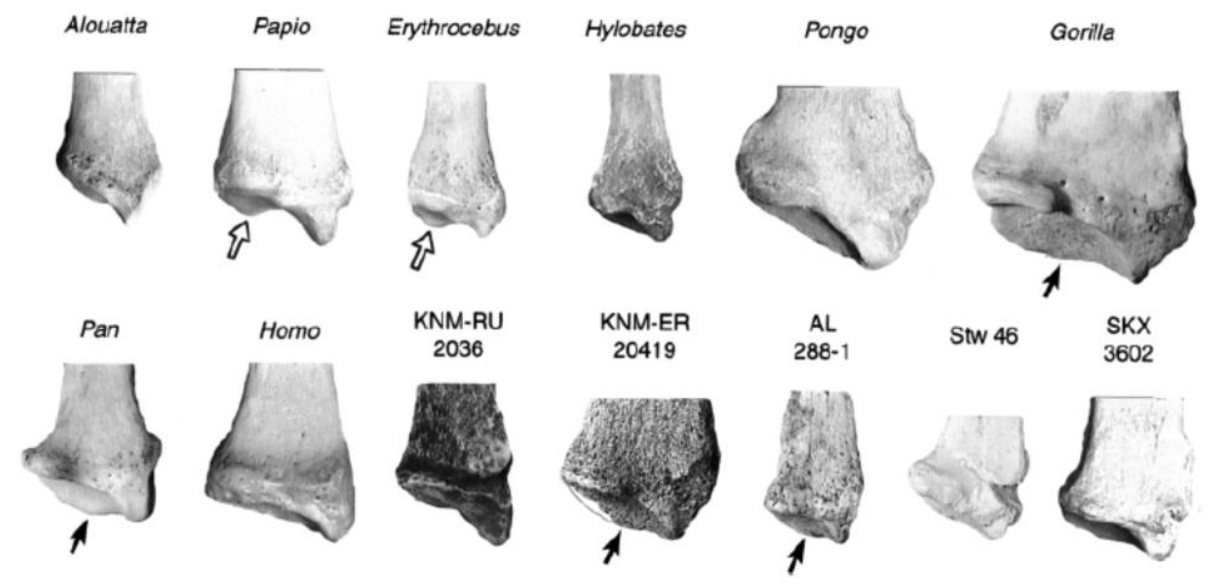

Gambar 1. Proyeksi Distalis radii pada fosil dalam penelitian

Panah menunjukkan proyeksi distalis ${ }^{1}$.

Pada komparasi radius dan memberi perlekatan pada tulangspatium carpometacarpalia tulang carpal sehinga mengakibatkan digunakan tulang/fosil dari primata articulatio radiocarpea akan lebih quadrupedal kemudian dibandingkan stabil. Proyeksi ini hanya ditemukan dengan homo bipedal. Fosil dari pada leluhur knuckle-walking dan alouatta, papio, erythrocebus, 
pada A. Anamensis dan A. terjadi tidak hanya sebagai lokomosi

Afarensis ${ }^{1}$

Spatium

carpometacarpalia

adalah ruang antara tulang-tulang

carpal dan tulang-tulang metacarpal.

Pada homo dan pan spatium ini

terlihat jelas. Semakinluas spatium

ini maka pergerakan sendi akan

semakin

fleksibel

dan

memungkinkan beberapa gerakan

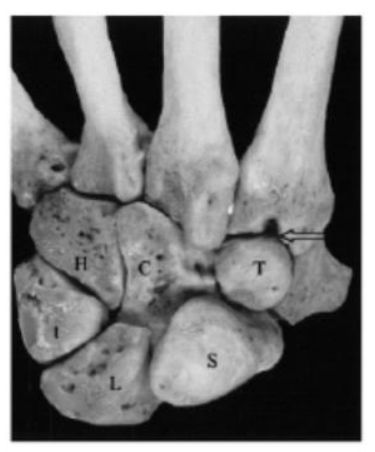

Homo

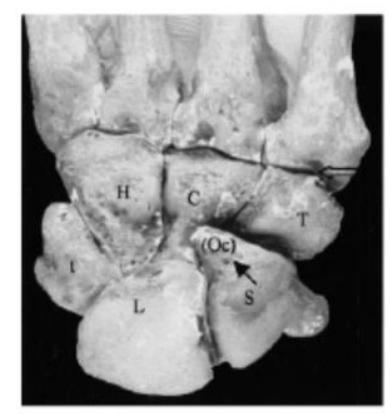

Pongo atau penyangga tubuh saja ${ }^{1}$.

Penelitian Danielson mem-

bandingkan antara permukaan sendi

proksimal femur dan humerus

manusia bipedal dan primata

quadrupedal. Pada penelitian ini ukuran caput femoris dan caput

humeri pada Homo sapiens dibandingkan dengan dua primata

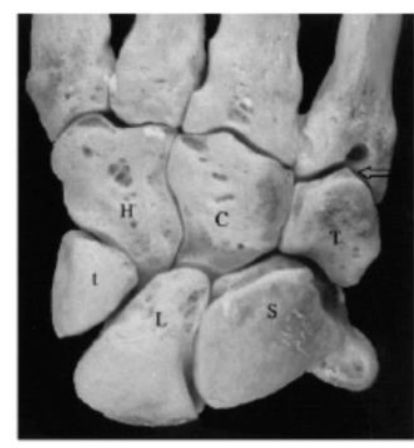

Pan

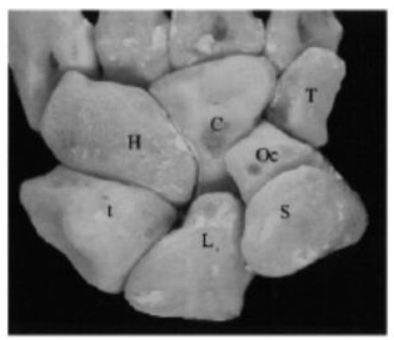

Papio

Gambar 2. Tulang carpal dan metacarpal pada beberapa fosil ${ }^{1}$ 
berbeda yaitu Cercocebus torquatus dan Cercocebus albigena. Tulang akan dipindai mengunakan komputer, dihitung kemudian dibandingkan menggunakan analisis statistik $^{2}$.

Rasio antara permukaan sendi pada caput humerus dan caput femoris pada $H$. Sapiens berbeda dengan primata. $C$. torquatus dan $C$. Albigena memiliki rasio yang serupa tetapi rasio tersebut lebih kecil dibandingkan pada $H$. Sapiens. Besarnya perbedaan pada permukaan sendi menunjukkan perbedaan permukaan sendi femoral yang jauh lebih besar daripada permukaan sendi humeral ${ }^{2}$.

Ukuran pada permkaan sendi ditemukan lebih besar pada manusia daripada primata. Perbedaan ini dimungkinkan karena lebih banyak beban yang diteruskan ke sendi femoral dibandingkan dengan sendi humeral pada manusia yang menggunakan lokomosi bipedal. Quadrupedal akan meneruskan beban secara relatif sama ke keempat tungkainya pada lokomosi quadrupedal. Semakin seimbang pembagian beban maka relatif ukuran tulang dan permukaan sendi yang menopang akan sama ${ }^{2}$.

Manusia menggunakan 2 sendi utama untuk lokomosi sehingga secara energi akan lebih efisien daripada lokomosi quadrupedal primata. Manusia merupakan mahluk bipedal yang menitikberatkan beban lebih banyak ke daerah femur daripada menitikberatkan beban pada daerah femur dan humerus seperti primata quadrupedal ${ }^{2}$.

Primata quadrupedal perlu menggunakan 4 sendi utama untuk lokomosi sehingga energi yang 
dibutuhkan akan lebih besar dan permukaan sendi baik femoral maupun humeral akan relatif sama pada primata quadrupedal ${ }^{2}$.

\section{KESIMPULAN}

Banyaknya teori yang berkembang mengenai asal usul bipedal dicoba dikaji menggunakan fosil-fosil untuk melihat hubungan anatomi yang terjadi dan sekarang diusulkan bahwa teori yang paling mendekati adalah leluhur quadrupedal arboreal dan leluhur knuckle-walking. Hal ini dilihat dari anatomi tangan dan kaki saat di darat, bentuk sokongan dan anatomi pergelangan tangan dan manus

Bentuk tulang pada manusia bipedal dan primata quadrupedal mirip tetapi terdapat perbedaan pada ukuran dan bentuk dari skeleton appendicularnya yang menyebabkan perbedaan pembagian/penerusan beban, berbedaan lokomosi dan perbedaan energi yang diperlukan untuk melakukan lokomosi.

\section{DAFTAR PUSTAKA}

1. Richmond BG, Begun DR, Strait, DS. Origin of Human Bipedalism:The Knuckle-Walking Hypothesis Revisited. YEARBOOK OF PHYSICAL ANTHROPOLOGY(2001). 44:70105. New York. 2001

2. Danielson K. A comparative look at the energetic efficiency of bipedal locomotion in humans versus quadrupedal locomotion in primates: measurements of femoral and humeral proximal head articular surface. University at Albany Honors College. (Thesis). New York. 2012

3. Kardong KV. Vertebrates. 5th Ed. McGraw-Hill:Singapore;2009

4. Jurmain R, Kilgore L, Trevatahan $\mathrm{W}$, Ciochon RL. Introduction to Physical Anthropology. 11th Ed. Thomson:California;2008 